\title{
8. Why justice is important
}

\author{
Catherine Gross
}

\section{Introduction}

Rural communities in the Murray-Darling Basin reacted with outrage, anger and protests after the release of the Murray-Darling Basin Authority (MDBA) Guide to the proposed Basin Plan on 8 October 2010. Regional and national newspapers gave the controversy full coverage. They reported standing room only at a series of regional community information sessions organised by the MDBA. These meetings were characterised by large gatherings of people from rural communities at which symbolic gestures - such as burning copies of the Guide in the streets - were clear demonstrations of frustration and anger (Jopson and Arup 2010). The mood was succinctly expressed in regional newspaper headlines - for example, the black background and red-lettered headline 'Fight Back' on the front page of the Victorian-based rural newspaper The Weekly Times. This headline was surrounded by a collage of photographs depicting protest signs (such as 'This Means War'), conveying widespread disagreement with the proposals outlined by the MDBA (Hunt 2010:1).

The Basin Plan has been long anticipated. Water reform in Australia has been high on the national agenda for the past two decades (Connell 2007). Since 1994, water reforms have taken progressive steps, culminating in the Water Act 2007, which brought water reform in the Murray-Darling Basin under an independent authority - the MDBA - for the first time, and required the MDBA to publish a Basin Plan under which sustainable levels of water extraction would be attained. The MDBA acknowledges the importance of engaging with stakeholders in the development of the Basin Plan, with key stakeholder groups being involved (MDBA 2010). So, it could be asked, with this length of time for anticipation and preparation, what went wrong? Why was the publication of the Guide greeted with such vehement opposition and why did rural communities receive MDBA representatives so angrily? Were these protests, therefore, merely expressions of 'self-interest', or what is known as 'rent seeking' in the Australian vernacular? Are irrigation communities simply seeking to preserve their perceived property rights in water? Or, are the protests manifestations of a broader set of rural and regional concerns and issues, which includes the wellbeing of rural communities and the way agricultural communities are valued by Australian society? The debate about water in Australia is highly complex and is characterised by firmly held notions and positions, including perspectives implied by these questions (see, for example, Crase 2008; Hussey and Dovers 2007). 
What is needed in situations in which there appears to be a 'stand-off' between various groups is a clearer understanding and appreciation of the perspectives held by stakeholders and an approach in which these can be understood and a useful dialogue can be developed and maintained. This chapter aims to provide some insights into the water-allocation debate through an exploration of perceptions of fairness and justice in two earlier social conflicts over water allocation in the Murray-Darling Basin (Gross 2008, 2010). The first centres on a 2006 NSW Government decision to cut the carry-over water allocation. This resulted in a community protest in the town of Deniliquin. The second social conflict is the community protest and campaign against the Victorian Government's North South Pipeline and Food Bowl Modernisation Project initiated in 2007. These two social conflicts were case studies in a larger research project exploring equitable resource allocation in environmental decision making (Gross 2010).

This chapter shows how perceived injustice in decision-making processes can be seen as a tangible harm to those involved and this in turn arouses a sense of injustice that impedes acceptance - not only of the decision, but also of the decision-making process itself. The chapter outlines several implications for decision makers concerning the need to recognise different types of justice in decision-making processes and the impact of perceived injustice on individuals and communities. The chapter makes the point that decision makers must recognise that not only outcomes need to be perceived as fair and equitable, but also decision-making processes and the way people are treated within decisionmaking processes.

\section{Fairness and Justice}

There is a sizeable body of research on fairness in natural-resource management in Australia and elsewhere (for example, Hunt and Haider 2001; Smith and McDonough 2001; Syme et al. 1999). There have, however, been many implementation challenges, as acknowledged by long-time Australian justice researchers Syme and Nancarrow (2008:242), who report that 'fairness is largely ignored despite the development in Australia of techniques to include it in a transparent fashion'. A key theme of fairness research in natural-resource management is the notion that decision-making processes that are perceived as fair are more likely to result in outcomes that are acceptable to those involved (Syme et al. 1999). In a study of water management in Europe, HophmayerTokich and Krozer (2008) investigated aspects of public participation and found that better decisions could be achieved if a range of perspectives and viewpoints in defining the problems could be incorporated. They commented 
that 'people are willing to co-operate if they sense that they are being treated fairly' (Hophmayer-Tokich and Krozer 2008:255). Thus, considerations of fairness are important in participation processes and decision making.

There has been a significant amount of research on fairness and justice in the discipline of social psychology. The idea of procedural justice came about in the mid 1970s when researchers realised that it was not only the outcome, or distributive justice, that was important to people, but that processes were also important (Colquitt et al. 2001). This was in contrast with the dominant idea of the time that outcomes were more important. Procedural justice includes several independent criteria that are required in decision-making processes. These include being able to participate in the process and to have one's voice heard; being able to access the right amount of information (summary or detail as required); enough time to be able to conduct research, debate the issue, and form an opinion; a mechanism in which issues can be raised, discussed and responded to; and finally, but not least, being treated with respect (Tyler 2000). This last criterion is often referred to as 'interactional justice'. Interactional justice is seen as being important enough to separate out from procedural justice because of the value and importance that people place on how they are treated-whether or not this is within a decision-making process (Bies 2001). Interactional justice is a broad approach to interpersonal treatment - for example, while it includes respectful treatment as in courteous interactions, it also includes whether people are involved, or given standing, in discussions about matters in which they have an interest. In summary, there are three main constructs of justice: interactional justice, concerned with respectful treatment; procedural justice, concerned with elements of the decision-making process; and distributive justice, concerned with the fairness of outcomes.

There is a further distinction that needs to be made: between justice and injustice. While much thought and research have been devoted to the notion of justice - for example, in philosophy, jurisprudence and political philosophyfar less has been expended on the notion of injustice (Simon 1995; Shklar 1990). While the notion of justice is frequently seen as difficult to define, with different meanings in different contexts, the notion of injustice is seen as more tangible and a cause of actual harm. This is in contrast with justice, which is seen as more of an ideal state to aspire to. Thus, injustice comes before justice and justice becomes the 'corrective to injustice' (Wolgast 1987:146). Simon (1995:16) puts the case for investigating a theory of injustice and argues that injustice 'empirically, temporally, psychologically and morally' comes before justice and these two notions should not be considered as the two sides of a coin. They are separate from each other and should be considered that way. This perspective was clearly articulated by Cahn (1949:13), reflecting on his years in the legal system, who wrote that justice should be seen as an 'active process of 
remedying or preventing what would arouse the sense of injustice' (emphasis in original). The experience of injustice, such as disrespectful treatment, can create harm and arouse a sense of injustice. Miller (2001:533) suggests that people perceive disrespectful treatment as an injustice because it 'deprives people of something to which they are entitled' and also 'subjects people to something they do not deserve'. Such explanations for why people react to perceived disrespectful treatment are important in the current context of water allocation in the Murray-Darling Basin.

A further area of justice is relevant in this context. This is the question of why people become engaged in matters of justice, or their motivation for justice. There are many theories about why people care about justice, and these can present a confusing picture. There are three broad groupings: that self-interest is the central motivation; that people care about justice because it indicates their status or value within a community or group; and that people care about justice because of its own intrinsic value, or as an end in itself (Montada 2003). The theory of self-interest has perhaps had the most influence as an explanation for why people care about justice: for material gain, to increase wellbeing or to protect one's livelihood. This theory has, however, been described as a myth because it has been seen to be overly dominant and because there are other valid explanations for why people seek justice (Tyler and Blader 2000). The second set of theories holds that people care about justice because it shows how they are valued within a group and involves their own self-worth within that group. The third area involves morality in which people can be motivated to achieve justice as an end in itself, perhaps as a means of ensuring stability in their social structure and environment (Lerner 1998). While these three groups have been viewed as competing models or theories, others see these as contextual motivations in which all can play a part depending on what types of disagreements or conflicts are taking place. Thus, it is possible that all of these motivations, to some degree, appear in individuals and groups within a community at the same time, depending on what type of injustice is perceived and how people perceive their current situation (Skitka 2009).

How people experience injustice has also been a topic of research. People have different experiences depending on their direct or indirect involvement and how they are affected by the perceived injustice. For example, there are the perspectives of the perceived victims, the perspectives of those responsible and the perspectives of bystanders - some of whom might be closely involved but are not directly affected and some of whom might be on the margins of the issue. In a social conflict, perceptions of injustice are by their nature subjective; the differing viewpoints of what is considered just or unjust are what lie at the heart of conflict and disagreement (Mikula 2005). 


\section{The Research}

The previous section has outlined some different areas of justice, including considerations of justice in interpersonal treatment, decision-making processes and outcomes, the distinction between justice and injustice, and why people become engaged in matters of justice. From this brief review it is evident that there is a complex interplay of interactions associated with these justice areas between decision makers, communities and individuals in a particular social context. Perceptions of injustice and motivations for justice are likely to be complex and experienced at different levels by different individuals within and around the communities affected.

As mentioned above, the research described in this chapter is part of a larger body of research into fairness and justice in natural-resource management. The first part of the research explored a community's reaction to a proposed wind farm in terms of the perceived fairness of the consultation process (Gross 2007). That research found that the principles of procedural justice were important in determining people's acceptance of the proposed wind farm. Many perceived that the proposed wind farm had damaged the community's overall wellbeing even before a final decision was made, because it had divided the community, and winners and losers had emerged. Thus, for some, the decisionmaking process itself had created a perceived injustice even before the final outcome was known. From that research, a trans-disciplinary investigative framework was developed (Gross 2008), using justice constructs and exploring people's engagement with fairness and justice on three different levels: material (concerned with family and livelihood), social (concerned with social wellbeing) and personal (concerned with values and beliefs) (Skitka 2003).

The two case studies, introduced above, were chosen because there were clear issues of fairness and justice involved in both disputes, as seen by the protests in both states and formation of an opposition group, Plug the Pipe, in Victoria. Both conflicts were reported in metropolitan newspapers and both were involved with water allocation in the Murray-Darling Basin. The 2006 NSW carry-over water issue arose because the NSW Government cut a water allocation for irrigators in the Murray Irrigation District following an extended period of drought. This was unexpected, and communities were taken by surprise. The cuts included traded water and carry-over water that was on irrigators' water accounts at the time of the announcement. Irrigators were surprised because they believed that the water allocation was secure, being primarily carried over from the previous year's water allocation as part of an agreed risk-management strategy. A second cut took place in November, following consultation with irrigation representatives. The community protested against the cuts by organising a rally in Deniliquin. The NSW Government later responded with an Extraordinary Assistance Package for farmers who were suffering hardship as a result of the drought. 
The second case study involves the combined Victorian project of the North South Pipeline and the Food Bowl Modernisation Project. The Victorian Government had agreed to fund upgrades to the ageing irrigation infrastructure in northern Victoria in return for a trade-off arrangement in which water would be diverted to Melbourne from the Goulburn River via the North South Pipeline. The dispute involved conflicting perspectives about the transfer of water from a rural area in drought to a coastal city that was perceived to have other options for water supply. Also disputed was the way the trade-off deal was perceived to have been constructed without adequate consultation between the government and differing sections of the communities affected by the deal.

Fieldwork for the research was carried out in New South Wales in early 2007 and in Victoria in late 2008. Semi-structured interviews were chosen as the most appropriate method in which a full range of perspectives of each social conflict could be explored. The interviews were based on a set of questions in which interviewees were asked to describe their involvement with the conflict, how it affected them materially, socially and personally, and their views on the fairness of the conflict from a process and outcome perspective. A networking approach to the interviews was used to select interviewees (by asking each interviewee to suggest other people to interview) and a variety of perspectives was achieved by selecting people from different stakeholder groupings. These included irrigators, dryland farmers, conservationists, business owners and employees, teachers, government agency employees and retirees. Confidentiality of the research was explained to all interviewees and was a key feature of the research. The interviews were recorded and the data transcribed and analysed.

\section{Finding Injustice and Seeking Justice}

\section{Respect, Process and Outcomes}

A wealth of information about fairness and justice was gathered from these interviews. The analysis presented here provides some insights into these social conflicts: a detailed analysis is provided in Gross (2010). The analysis uses a justice lens to explore people's perceptions of the decision-making processes, and their views of the impact of the proposed or actual outcomes on themselves and their community.

The first key finding in this research was that people talked about un fairness and in justice rather than fairness and justice. They talked about what was wrong within the social conflict and how it had already affected them. Many described their fears for the future following the events that had taken place. These perceptions of injustice varied according to people's circumstances, 
and whether they were directly or indirectly affected on a material, social or personal level. For example, those who had experienced the NSW irrigation cutbacks could be materially affected by the loss of water and impact on their business. In contrast, others in the community were affected only indirectly but were concerned about the plight of their neighbours, family or friends within the community who might be harder hit by the cuts. It was not, however, only the material impacts that were perceived to be unjust, but also the way the communities felt they had been treated.

Many members of the community in the Yea district in Victoria were concerned with the lack of communication and consultation by the Victorian Government in discussing the details and impact of the proposed North South Pipeline. Some were concerned with the impact of the pipeline on their agricultural business, whereas others were more concerned with the diversion of water from the Goulburn River and the impact on the environment and others relying on the Goulburn River for their business. These perceived injustices regarding process, or the lack of consultation and opportunities for discussion, also spread into personal concerns about the willingness of government agencies to provide information and how they conducted their business in these types of infrastructure developments. Major concerns in this area were the lack of available information about the proposed savings of water from the irrigation infrastructure upgrade and the lack of information on other options or any detailed justification for the diversion of water to Melbourne.

Thus, it can be seen that these perceived injustices were related not only to the proposed outcome, but also to decision-making processes and the way people were treated during those processes. These perceived injustices and others described by interviewees are summarised in Tables 8.1 and 8.2 and are listed in order of the type of justice construct perceived to be violated.

Table 8.1 Perceptions of injustice in the NSW study

\begin{tabular}{l|l}
\multicolumn{1}{c|}{ Perception of injustice } & \multicolumn{1}{c}{$\begin{array}{c}\text { Type of justice } \\
\text { violated }\end{array}$} \\
\hline Lack of respect in the way people were treated & Interactional justice \\
\hline Lack of notification, information and involvement & Procedural justice \\
\hline Perceived entitlement/property removed & Distributive justice \\
\hline Burden of cutback inequitably distributed amongst irrigator groups & Distributive justice \\
\hline Lack of recognition of actual harm done & Distributive justice \\
\hline Equitable compensation not offered & Distributive justice \\
\hline Inequity of Extraordinary Assistance Package & Distributive justice \\
\hline
\end{tabular}


Table 8.2 Perceptions of injustice in the Victorian study

\begin{tabular}{|c|c|}
\hline Perception of injustice & $\begin{array}{l}\text { Type of justice } \\
\text { violated }\end{array}$ \\
\hline Disdainful treatment of affected communities & Interactional justice \\
\hline To break an election promise and lie in meetings & Interactional justice \\
\hline $\begin{array}{l}\text { Lack of consultation regarding initiation of pipeline and irrigation } \\
\text { modernisation project }\end{array}$ & Procedural justice \\
\hline Lack of information on pipeline and water savings & Procedural justice \\
\hline To continue the process with inadequate consultation & Procedural justice \\
\hline $\begin{array}{l}\text { Lack of an environmental assessment to consider the combined } \\
\text { impact of the pipeline and the irrigation upgrade }\end{array}$ & Procedural justice \\
\hline $\begin{array}{l}\text { Impact on the environment: removal of water from river system } \\
\text { and loss of water flow }\end{array}$ & Distributive justice \\
\hline $\begin{array}{l}\text { Proposal based on unsatisfactory justification of 'need' when } \\
\text { other options for increasing Melbourne's water supply had not } \\
\text { been fully explored }\end{array}$ & Distributive justice \\
\hline $\begin{array}{l}\text { To remove water from irrigators who have paid for it through their } \\
\text { annual fees and capital purchase }\end{array}$ & Distributive justice \\
\hline $\begin{array}{l}\text { To base the project on future water savings that are not validated } \\
\text { and contested }\end{array}$ & Distributive justice \\
\hline
\end{tabular}

These tables show that perceived injustices arose in all three areas in both studies. In the Victorian study there was an emphasis on perceptions of injustice in the decision-making processes because interviews were conducted prior to significant infrastructure works taking place. In the NSW study the outcome, or decision, had already been put into action and perceived inequities associated with the government's Extraordinary Assistance Package had become apparent to some in the community.

\section{Injustice as Harm to Community Wellbeing}

I put confidence under a personal banner. We are struggling to keep the confidence level up with all these changes... we need some sort of belief in the future.

[I]t has hurt the community because it has destabilised the community... what underpins communities is partly the ability of people to be optimistic, to be positive about the future, therefore they are prepared to invest...yet that action has destabilised those sorts of things. 
These two quotations from community leaders interviewed in the NSW study summarise their view of the lasting negative impact and harm that perceived unfair treatment can have on communities. These quotations reflect the importance of a strong belief in the future for the overall wellbeing of the community. Regional communities that rely on irrigation for a substantial part of their material livelihood also rely on confidence in their relationships with government. A significant adverse impact of the NSW carry-over water cutbacks study was that this was perceived as yet another blow to community confidence on top of a series of what were perceived to be unsatisfactory governmentcommunity interactions. A community leader who had spent a significant amount of time on committees dealing with government agencies lamented the fact that social impacts were routinely overlooked and that it is an awfully long haul to try and get governments to listen to what the real issues are for communities'.

Another recurring theme was the perceived injustice in the way irrigators are regarded in general by society. For example, a vegetable grower pointed out the irony of a news headline that had reported on the recent $\$ 10$ billion plan put forward by the then Prime Minister, John Howard. The headline stated: 'Mr Howard is giving money to farmers to stop them wasting water.' In the vegetable grower's opinion, irrigators were held at the 'lowest level' when it came to water use, and this headline underscored the lack of understanding of the use of irrigation water in food production. Many community members in both case studies commented on the perceived rural-urban divide and what they believed was a lack of knowledge in society in general about how irrigation water is used and the value of different types of annual crops, such as rice, in making use of irrigation water when it is available.

\section{Seeking Justice}

As outlined in the 'Fairness and Justice' section above, there are many reasons why people are motivated to seek justice. In both studies individuals and communities were strongly motivated to voice their disagreement and to seek some sort of measure to restore the perceived injustice. It is possible to categorise some emerging themes with respect to the type of motive for justice and proposed measure to restore justice for each perception of injustice. A summary of some emerging themes from the NSW case study is outlined in Table 8.3. 
Table 8.3 Community injustice framework: some emerging themes from the NSW study

\begin{tabular}{|c|c|c|}
\hline $\begin{array}{l}\text { Community perceptions } \\
\text { of the issues and } \\
\text { associated injustice }\end{array}$ & $\begin{array}{l}\text { Proposed measure to } \\
\text { restore justice }\end{array}$ & $\begin{array}{l}\text { Possible underlying } \\
\text { motive for justice }\end{array}$ \\
\hline $\begin{array}{l}\text { - Lack of recognition of } \\
\text { impact } \\
\text { - Carry-over water cutbacks } \\
\text { as a violation of a property } \\
\text { right } \\
\text { - Lack of consultation } \\
\text { - Lack of respect for local } \\
\text { knowledge } \\
\text { - Lack of recognition for } \\
\text { contribution to society as an } \\
\text { agricultural community }\end{array}$ & $\begin{array}{l}\text { - Recognition of social impact } \\
\text { - Equitable compensation for } \\
\text { the water removed } \\
\text { - Consultation that respects } \\
\text { local knowledge and local } \\
\text { perspectives } \\
\text { - Government agencies } \\
\text { to recognise value of } \\
\text { agricultural production }\end{array}$ & $\begin{array}{l}\text { - Protection of interests } \\
\text { of community: mutual } \\
\text { advantage } \\
\text { - Protection of livelihood } \\
\text { - Justice as an end in itself- } \\
\text { to do the right thing } \\
\text { - To maintain structural } \\
\text { stability of the community } \\
\text { and confidence in the future } \\
\text { - Community to be valued for } \\
\text { contribution to society }\end{array}$ \\
\hline
\end{tabular}

This summary shows a complex interplay within the community of perceived injustices and underlying motives to restore justice, depending on the perspective and involvement of the individual or group. This type of categorisation is useful in developing an understanding of the different perspectives held by differing individuals and groups within a social conflict.

Through the lens of injustice, this section has shown some perspectives and consequences of a variety of perceived injustices on individuals and communities. Calls for justice from such communities include that communities should be treated with respect, information should be provided, harm should be recognised, impacts should be understood and dealt with on a fair basis and wrongs should be righted.

\section{Implications for Decision Makers}

There are several implications for decision makers. The first is to recognise that there are different types of perceived injustice in decision making. Perceived injustices can arise in three main areas: in the way people are treated (interactional injustice); as a result of inadequacies in components of the decision-making process (procedural injustice); and as a consequence of the outcome or decision (distributive injustice). A consultation process that fails to deliver what people expect - such as real engagement in the process, being treated with respect, being given information that supports proposed decisions, time to understand and discuss information and implications - will be perceived as an injustice to those involved. The key point here is that consultation processes either can deliver fairness and justice if they include these elements, or can deliver perceived injustice if these elements are omitted. 
A second implication is that a perceived injustice constitutes an actual harm to an individual or community, whether it is part of a process or an outcome. The harm can be manifested on a material, social or personal level. The perceived injustice can take the form of an outcome as part of a failure in the consultation process, such as a failure to be consulted or to consider the impact of a proposed decision. A harm resulting from a perceived injustice can have a significant long-term impact on individual and community confidence and belief in future security. Another aspect for decision makers to consider is that a harm resulting from a perceived injustice arouses a sense of injustice and incites opposition to the decision-making entity and proposed outcomes. Thus - and importantly for decision makers - acceptance of decisions is impeded by perceived injustice.

A third implication is that perceived injustices require justice in order to resolve them. If perceived injustices are not resolved then there is a build-up of perceived layers of injustice that not only results in communities feeling undervalued or badly treated, but also undermines their ability to meaningfully engage in government processes due to resentment and 'burn-out'.

Finally, a fourth implication that can be drawn from this analysis is that decision makers must understand their role in bringing out the different perspectives and viewpoints held by individuals and communities in decision-making processes. This analysis has shown that 'self-interest' is but one of many different perspectives in the water-allocation debate. Better outcomes could be achieved if these different perspectives could be acknowledged, respected and debated by society at large. This is why the term 'justice must be done and must be seen to be done' is important.

In conclusion, it is vital that decision makers understand the importance of the different types of justice when engaging with people in consultation processes and decision-making processes. Decision makers must understand the longterm consequences on communities and why acceptance of outcomes is harder to obtain if they fail to devise and deliver decision-making processes that those involved can perceive as just and fair.

\section{Acknowledgments}

Thanks to interviewees in New South Wales and Victoria for sharing their perceptions about fairness and justice. The research was funded by a Land \& Water Australia scholarship. 


\section{References}

Bies, R. J. 2001, 'Interactional (in)justice: the sacred and the profane', in J. Greenberg and R. Cropanzano (eds), Advances in Organisational Justice, Stanford University Press, Calif., pp. 89-118.

Cahn, E. N. 1949, The Sense of Injustice: An anthropocentric view of law, New York University Press, Manhattan.

Colquitt, J. K., Conlon, D. E., Wesson, M. J., Porter, C. O. and Ng, K. Y. 2001, 'Justice at the millennium: a meta-analytic review of 25 years of organisational justice research', Journal of Applied Psychology, vol. 86, no. 3, pp. 425-45.

Connell, D. 2007, Water Politics in the Murray-Darling Basin, The Federation Press, Sydney.

Crase, L. (ed.) 2008, Water Policy in Australia: The impact of change and uncertainty, Resources for the Future, Washington, DC.

Gross, C. 2007, 'Community perspectives of wind energy in Australia: the application of a justice and community fairness framework to increase social acceptance', Energy Policy, vol. 35, no. 5, pp. 2727-36.

Gross, C. 2008, 'A measure of fairness: an investigative framework to explore perceptions of fairness and justice in a real-life social conflict', Human Ecology Review, vol. 15, no. 2, pp. 130-40.

Gross, C. 2010, Water under the bridge: fairness and justice in environmental decision-making, PhD Thesis, The Australian National University, Canberra, $<$ http://dspace-prodl.anu.edu.au/handle/1885/49419>

Hophmayer-Tokich, S. and Krozer, Y. 2008, 'Public participation in rural area water management: experiences from the North Sea countries in Europe', Water International, vol. 33, no. 2, pp. 243-57.

Hunt, P. 2010, 'Fight back', The Weekly Times, Wednesday, 20 October 2010.

Hunt, L. and Haider, W. 2001, 'Fair and effective decision-making in forest management planning', Society and Natural Resources, vol. 14, 873-87.

Hussey, K. and Dovers, S. (eds) 2007, Managing Water for Australia: The social and institutional challenges, CSIRO Publishing, Collingwood, Vic.

Jopson, D. and Arup, T. 2010, 'Irrigators vent fury at proposed water cuts', Sydney Morning Herald, 13 October 2010, viewed 24 October 2010, <http:// www.smh.com.au/environment/water-issues/irrigators-vent-fury-atproposed-water-cuts-20101013-16k41.html> 
Lerner, M. J. 1998, 'The two forms of belief in a just world: some thoughts on why and how people care about justice', in L. Montada and M. J. Lerner (eds), Responses to Victimisations and Belief in a Just World, Plenum Press, New York, pp. 247-69.

Mikula, G. 2005, 'Some observations and critical thoughts about the present state of justice theory and research', in S. W. Gilliland (ed.), What Motivates Fairness in Organisations?, Information Age Publishing, Greenwich, Conn., pp. 197-210.

Miller, D. T. 2001, 'Disrespect and the experience of injustice', Annual Review of Psychology, vol. 52, p. 527.

Montada, L. 2003, 'Justice, equity, and fairness in human relations', in I. B. Weiner (ed.), Handbook of Psychology. Volume 5, Wiley, New York, pp. 53768 .

Murray-Darling Basin Authority (MDBA) 2010, Guide to the proposed Basin Plan, Murray-Darling Basin Authority, Canberra, viewed 24 October 2010, $<$ http://www.mdba.gov.au/basin_plan>

Simon, T. W. 1995, Democracy and Social Injustice: Law, politics, and philosophy, Rowman \& Littlefield Publishers, Lanham, Md.

Shklar, J. 1990, The Faces of Injustice, Yale University Press, New Haven, Conn.

Skitka, L. J. 2003, 'Of different minds: an accessible identity model of justice reasoning', Personality and Social Psychology Review, vol. 7, no. 4, pp. 28697.

Skitka, L. J. 2009, "Exploring the "lost and found" of justice theory and research', Social Justice Research, vol. 22, no. 1, pp. 98-116.

Smith, P. D. and McDonough, M. H. 2001, 'Beyond public participation: fairness in natural resource decision making', Society \& Natural Resources, vol. 14, pp. 239-49.

Syme, G. and Nancarrow, B. 2008, 'The social and cultural aspects of sustainable water use', in L. Crase (ed.), Water Policy in Australia: The impact of change and uncertainty, Resources for the Future, Washington, DC, pp. 230-42.

Syme, G., Nancarrow, B. and McCreddin, J. A. 1999, 'Defining the components of fairness in the allocation of water to environmental and human uses', Journal of Environmental Management, vol. 57, no. 1, p. 51.

Tyler, R. T. 2000, 'Social justice: outcome and procedure', International Journal of Psychology, vol. 35, no. 2, pp. 117-25. 
Basin Futures

Tyler, R. T. and Blader, S. L. 2000, Cooperation in Groups: Procedural justice, social identity, and behavioral engagement, Psychology Press, Philadelphia.

Wolgast, E. H. 1987, The Grammar of Justice, Cornell University Press, Ithaca, NY. 